\title{
Acetylation of peptides inhibits their degradation by rumen micro-organisms
}

\author{
BY R. J. WALLACE \\ Rowett Research Institute, Bucksburn, Aberdeen AB2 9SB
}

(Received 15 April 1991-Accepted 19 September 1991)

\begin{abstract}
Proteins and peptides were acetylated using acetic anhydride in order to block their N-terminal amino groups and thereby to prevent their hydrolysis by rumen microbial aminopeptidases. The effects of acetylation on peptide breakdown and ammonia production were determined by incubating unmodified and acetylated substrates with sheep rumen micro-organisms in vitro. Ammonia production from casein and lactalbumin was affected little by acetylation, but acetylation of the corresponding enzymic hydrolysates caused ammonia production to be more than halved after $3-6 \mathrm{~h}$ incubation. Estimation of peptides remaining in rumen fluid showed that the decreased ammonia production was a consequence of peptides being hydrolysed more slowly. Acetylated Ala-Ala, Ala-Ala-Ala (Ala 3 ), Leu-Gly-Gly, Phe-GlyGly and Val-Gly-Ser-Glu survived incubation with rumen fluid in vitro for $6 \mathrm{~h}$, whereas almost none of the corresponding unmodified peptides was present at $6 \mathrm{~h}$. The protection afforded to larger pure peptides was less reliable: for example, $72 \%$ of acetylated bradykinin was hydrolysed after $1 \mathrm{~h}$. $\mathrm{N}$-Acetyl Ala had only a minor inhibitory effect on the breakdown of $\mathrm{Ala}_{3}$ and $\mathrm{Ala}_{4}$, suggesting that although acetyl peptides were broken down more slowly than unmodified peptides they did not inhibit peptidase activity.
\end{abstract}

Rumen peptide breakdown: Protection by acetylation: Sheep

The intervention of rumen fermentation can have two main detrimental effects on the protein nutrition of ruminants. First, breakdown of protein to ammonia in the rumen frequently leads to rates of ammonia production that exceed microbial requirements for growth (Tamminga, 1979; Leng \& Nolan, 1984). The excess ammonia diffuses across the rumen wall, and is eventually excreted in the form of urea (Nolan, 1975). Second, the microbial protein formed by the fermentation contains less than ideal proportions of some essential amino acids, notably methionine and lysine (Storm \& Ørskov, 1984). Supplementation with essential amino acids is made difficult because they are rapidly degraded in rumen contents (Chalupa, 1976; Broderick \& Balthrop, 1979). Thus, decreasing the breakdown of proteins or amino acids in the rumen and correcting the amino acid imbalance in the protein flowing from the rumen would each contribute to improving the efficiency of nitrogen retention by the animal.

Attempts to overcome the problems associated with rumen microbial protein breakdown have focused mainly on chemical or physical mechanisms for preventing the degradation of dietary protein (Kaufmann \& Lupping, 1982; Broderick et al. 1991) or for protecting individual amino acids from breakdown in the rumen (Ferguson, 1975; Kaufmann \& Lupping, 1982). Peptides are intermediates in the breakdown process (Annison, 1956), but protection of peptides from rumen degradation has received little attention.

It has now been established that the predominant mechanism for hydrolysis of peptides by rumen micro-organisms is a dipeptidyl aminopeptidase-like activity, which cleaves dipeptides from the $\mathrm{N}$-terminus of the peptide chain (Wallace \& McKain, 1989; Wallace et al. 1990). The aim of the present study was to investigate whether blocking the $\mathrm{N}$ - 
terminus of peptides by acetylation was a potential means of inhibiting peptide breakdown in the rumen. A preliminary account of some of the present work has already been published (Wallace, 1991).

\section{MATERIALS AND METHODS}

\section{Animals}

Four adult sheep, fitted with permanent rumen cannulas, received a maintenance diet of hay, barley, molasses, fish meal and vitamins-minerals mix $(500,299 \cdot 5,100,91$ and 9.5 $\mathrm{g} / \mathrm{kg}$ dry matter (DM) respectively). Samples of rumen fluid were removed between 1.5 and $2.5 \mathrm{~h}$ after feeding. These samples were strained through four layers of muslin and used immediately.

\section{Acetylation of proteins and peptides}

Acetylation was carried out using acetic anhydride as described by Means \& Feeney (1964). Protein or peptide was dissolved in saturated sodium acetate solution at a concentration of $100 \mathrm{~g} / 1$ and chilled in an ice-water slurry. Five portions $(20 \mathrm{ml} / 1$ solution $)$ of acetic anhydride were added at 10 min intervals and the mixture was incubated at $4^{\circ}$ for $24 \mathrm{~h}$.

Solutions of acetylated proteins and the original proteins were dialysed against distilled water for $2 \mathrm{~h}$ to remove reagents, then freeze-dried. Acetylated peptides were prepared in different ways according to the experiment. In Expt 2, the reaction mixtures containing acetyl peptides were applied to a column $(560 \times 16 \mathrm{~mm})$ of Sephadex G-10, which was eluted with distilled water at $2.7 \mathrm{ml} / \mathrm{min}$. The effluent was collected for $26 \mathrm{~min}$, at which time acetate began to elute. The effluent was then freeze-dried. Unmodified peptides were dissolved in sodium acetate solution, chromatographed and freeze-dried in a similar way. It was estimated from their elution profiles that 15\% of Trypticase and lactalbumin hydrolysate, presumably the smallest peptides in the mixtures, were lost during this procedure. In the other experiments, solutions containing acetylated peptides were dried at $60^{\circ}$ for $18 \mathrm{~h}$ and no attempt was made to remove the sodium acetate.

\section{Incubations with rumen fluid in vitro}

Expt 1. Ala-Ala-Ala $\left(\mathrm{Ala}_{3}\right)$ and $\mathrm{N}$-acetyl $\mathrm{Ala}_{3}$ were added to strained rumen fluid from each of the four sheep to a final peptide concentration of $2 \mathrm{~g} / \mathrm{l}$, and the mixtures were incubated under carbon dioxide in stoppered containers in a shaking water-bath at $39^{\circ}$. Samples $(1.0$ $\mathrm{ml})$ were removed periodically into microcentrifuge tubes containing $0.25 \mathrm{ml}$ trichloroacetic acid $(250 \mathrm{~g} / 1)$. Tubes were chilled at $4^{\circ}$ and centrifuged $(12000 \mathrm{~g}, 5 \mathrm{~min})$, and peptide analysis was done on the supernatant fluid.

Expt 2. Proteins, protein hydrolysates and acetylated preparations of the same materials were added to strained rumen fluid from each of the four sheep to a final peptide concentration of $2 \mathrm{~g} / \mathrm{l}$, and the mixtures were incubated, acidified and centrifuged as in Expt 1. Analyses for ammonia and peptides were done on the supernatant fluid. Parallel incubations were done with no added protein or peptide. Ammonia and peptide concentrations in control incubations were subtracted from those in which proteins or peptides were added in order to determine net ammonia production or peptide disappearance.

Expt 3. In order to reduce the quantities of pure compounds required for the experiment, samples of rumen fluid from the four sheep were pooled before use, and duplicate incubations of the pooled mixtures were done as for Expt 1. Sample volumes were $0.2 \mathrm{ml}$ added to $0.05 \mathrm{ml} 1.25 \mathrm{M}$-phosphoric acid, which was used in preference to trichloroacetic acid in order to facilitate subsequent high-performance liquid chromatographic (HPLC) analysis. Samples were chilled and centrifuged as before. 
Expt 4. Strained rumen fluid $(30 \mathrm{ml})$ from each sheep was mixed with $10 \mathrm{ml}$ anaerobic $25 \mathrm{~mm}$-potassium phosphate buffer, $\mathrm{pH} 7 \cdot 0$. Portions $(0.6 \mathrm{ml})$ were added to microcentrifuge tubes containing $0.1 \mathrm{ml}$ Ala-Ala $\left(\mathrm{Ala}_{2}\right)$ or $\mathrm{Ala}_{3}(10 \mathrm{~mm}$ in anaerobic buffer) and $0.1 \mathrm{ml}$ anaerobic buffer or $25 \mathrm{~mm}-N$-acetyl $\mathrm{Ala}_{3}$ in anaerobic buffer. The reaction was

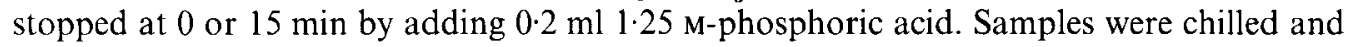
centrifuged as described previously.

\section{Analyses}

Ammonia was determined in the supernatant fluid by an automated phenol-hypochlorite method (Whitehead et al. 1967). The protein content of strained rumen fluid was measured using the Folin reagent following alkaline digestion (Herbert et al. 1971). The concentration of individual peptides and acetyl peptides in supernatants, and also the efficacy of the acetylation procedure, were determined by hydrophobic ion-pairing HPLC using a reversephase C18 column (Wallace \& McKain, 1989). The extent to which Trypticase and lactalbumin hydrolysate were modified was determined using the fluorescamine described previously (Broderick \& Wallace, 1988), except that fluorescamine was dissolved in methanol rather than acetone.

The concentrations of mixed peptides and acetyl peptides in the supernatant fluid were determined by passing the fluid through a column of Sephadex G-25 Superfine $(820 \times 10$ $\mathrm{mm}$ ) and collecting all fractions up to a $\mathrm{V}_{\mathrm{e}} / \mathrm{V}_{\mathrm{o}}$ of $2 \cdot 29$, which corresponds to a peptide molecular weight of $300 \mathrm{Da}$ (Wallace, 1992). Volatile fatty acids began to elute at this volume preventing the analysis of peptides by u.v. absorption in later fractions. The absorbance at $206 \mathrm{~nm}\left(A_{206}\right)$ of peptide-containing samples was compared with that of controls to which no peptide or protein had been added. The difference in $A_{206}$ was used to calculate the concentration of peptides remaining at each time, assuming that the extinction coefficient of the peptides was the same as that of Trypticase $(20 \cdot 2$ for a $1 \mathrm{~g} / 1$ solution). This rather complicated procedure for estimating peptides was adopted because the usual amino group reagents such as ninhydrin, $o$-phthalaldehyde and fluorescamine do not react with acetyl peptides.

\section{Materials}

Trypticase is a pancreatic hydrolysate of casein, obtained from BBL Microbiology Systems, Cockeysville, Maryland, USA. Lactalbumin hydrolysate L48 was obtained from Oxoid Ltd, Basingstoke. Val-Gly-Ser-Glu was obtained from Bachem AG, Bubendorf, Switzerland. Other peptides and fine chemicals were supplied by Sigma Chemical Company Ltd, Poole, Dorset.

\section{RESULTS}

Expt 1. The rates of hydrolysis of $\mathrm{Ala}_{3}$ and $\mathrm{N}$-acetyl $\mathrm{Ala}_{3}$ were compared by incubating the peptides in rumen fluid in vitro and determining the disappearance of $\mathrm{Ala}_{3}$ and $\mathrm{N}$-acetyl $\mathrm{Ala}_{3}$ by HPLC. More than half the unmodified $\mathrm{Ala}_{3}$ had disappeared after $1 \mathrm{~h}$, whereas only $49 \%$ of $N$-acetyl $\mathrm{Ala}_{3}$ was lost in 24 h (Fig. 1).

Expt 2. Treatment of Trypticase and lactalbumin hydrolysate with acetic anhydride resulted in the blocking of 92.7 and $92.3 \%$ of $\mathrm{N}$-terminus amino groups respectively, as determined by fluorescamine reactivity. The efficiency of substitution of casein and albumin was not determined. The acetylation procedure caused casein to produce ammonia at a slightly increased rate compared with the unmodified protein (Fig. 2(a)). Ammonia production was not similarly affected by acetylating lactalbumin (Fig. 2(b)). The effects on ammonia production from Trypticase and lactalbumin hydrolysate were much clearer in that significant decreases were observed at 3 and $6 \mathrm{~h}$ and the trend continued thereafter 


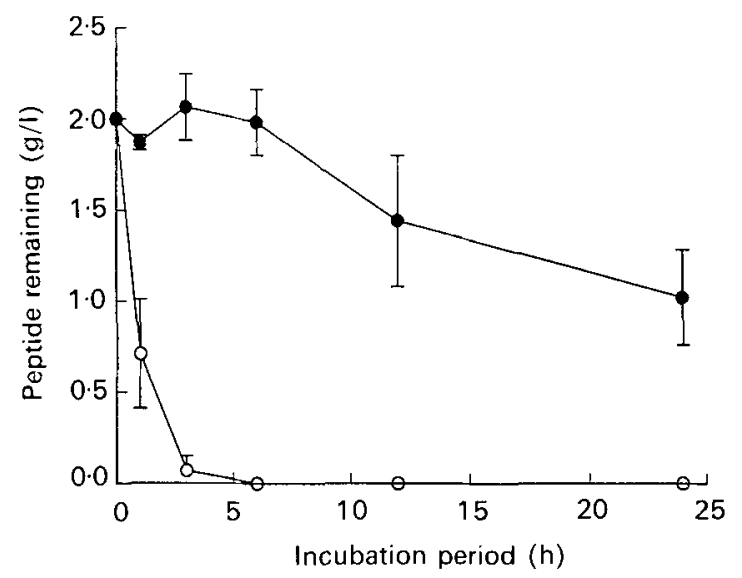

Fig. 1. Disappearance of $\mathrm{Ala}_{3}(\mathrm{O})$ and $\mathrm{N}$-acetyl $\mathrm{Ala}_{3}(\mathrm{O})$ added to rumen fluid in vitro. Results are means and standard deviations represented by vertical bars for samples of rumen fluid taken from four sheep. For details of procedures, see pp. 366-367.

(Fig. 2(c,d)). The decreased ammonia production from acetyl Trypticase was confirmed to be due to a decreased breakdown of peptides rather than an accumulation of amino acids (Fig. 3). The difference in remaining peptides was greatest at $12 \mathrm{~h}$.

Expt 3. When individual pure peptides were added to rumen fluid, all were broken down rapidly so that $5 \%$ or less remained after $6 \mathrm{~h}$ (Table 1). Acetylated pure peptides were generally more stable. No hydrolysis of acetylated Val-Gly-Ser-Glu, Phe-Gly-Gly, LeuGly-Gly, $\mathrm{Ala}_{3}$ or Ala $\mathrm{Al}_{2}$ occurred in $6 \mathrm{~h}$. The hydrolysis of bradykinin, angiotensin III and Gly-Gly-Phe-Leu was slowed, but not enough to prevent the almost complete removal of these compounds after $6 \mathrm{~h}$. In contrast, Arg-Lys-Asp-Val-Tyr was more rapidly degraded in the acetylated form.

Expt 4. The influence of $\mathrm{N}$-acetyl $\mathrm{Ala}_{3}$ on peptide breakdown was determined by adding

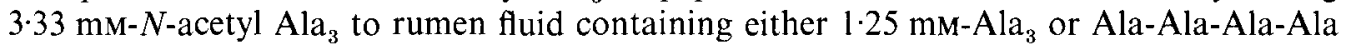
$\left(\mathrm{Ala}_{4}\right)$. A slight inhibition of $\mathrm{Ala}_{3}$ and $\mathrm{Ala}_{4}$ hydrolysis occurred (Table 2). However, the magnitude of these effects was small, the mean rates of hydrolysis being decreased by only 12 and $14 \%$ respectively.

\section{DISCUSSION}

In earlier experiments which identified dipeptidyl aminopeptidase as the predominant mechanism for the hydrolysis of peptides in the rumen, $N$-acetyl $\mathrm{Ala}_{3}$ was not significantly hydrolysed in rumen fluid in a 20 min incubation (Wallace \& McKain, 1989). In the present study no significant hydrolysis of Ala $_{3}$ occurred after $6 \mathrm{~h}$ incubation with rumen fluid in vitro, and half a $2 \mathrm{~g} / 1$ addition remained after $24 \mathrm{~h}$. This degree of protection, if it could be applied to other peptides and if protection could be sustained in vivo, would offer a possible new method for delivering essential amino acids in the form of $N$-acetyl peptides to the small intestine in ruminants.

Proteins, protein hydrolysates and pure peptides were acetylated using acetic anhydride and the effect of acetylation on the rates of degradation of the peptides was determined. The degree to which acetylation afforded protection from degradation varied. Some di- and tripeptides were made resistant to the same degree as $\mathrm{Ala}_{3}$. Protection of some larger pure peptides and of the enzymic protein hydrolysates was incomplete, however, despite $>90 \%$ modification of the free amino groups. Acetylation had no protective effect for intact casein or lactalbumin. 

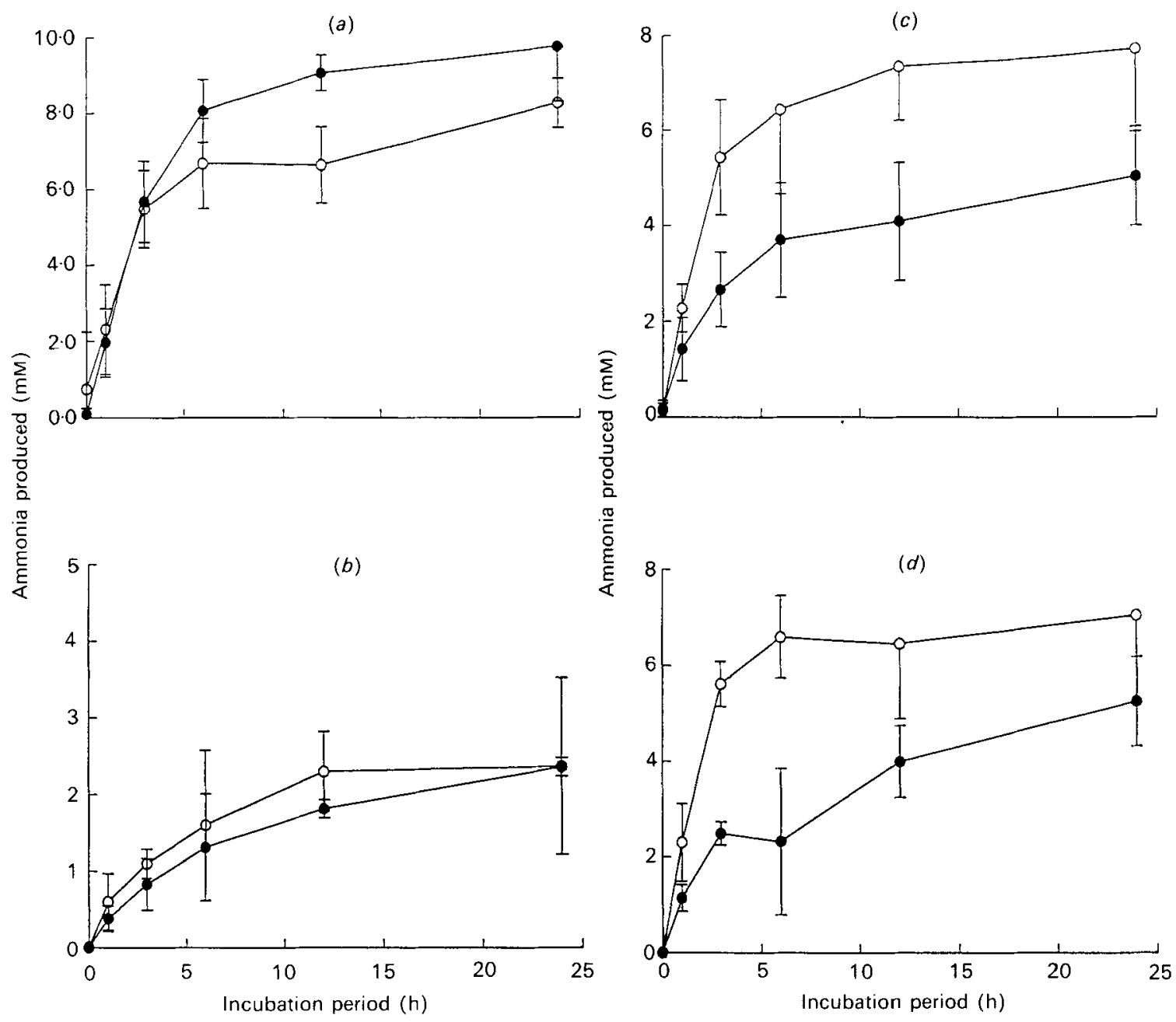

Fig. 2. Influence of acetylation on ammonia production from proteins and protein hydrolysates incubated in rumen fluid in vitro. (O), Unmodified substrate; $(\mathbf{O})$, acetylated substrate. (a) Casein, (b) lactalbumin, (c) Trypticase, $(d)$ lactalbumin hydrolysate. Results are means and standard deviations represented by vertical bars for samples of rumen fluid taken from four sheep. For details of procedures, see pp. 366-367.

Presumably these results reflect a dependence on molecular size and the relative importance of peptidases (exopeptidases) and proteinases (endopeptidases) in breaking down peptide chains of different length. As chain length increases, the number of bonds subject to endopeptidolytic cleavage will increase. Eventually, in the intact proteins, initial exopeptidase cleavage will become insignificant compared with the effects of endopeptidases, and as a result acetylation will have no effect. Much will depend on whether the sequence of the acetylated peptide contains bonds susceptible to the main rumen microbial proteases. Nevertheless, it would appear that small peptides of only two or three amino acid residues and perhaps certain other larger molecules may be effectively protected by acetylation.

During the course of these experiments two gel filtration techniques were used, first to separate acetylated peptides from other reagents in the mixture, and second to estimate the 


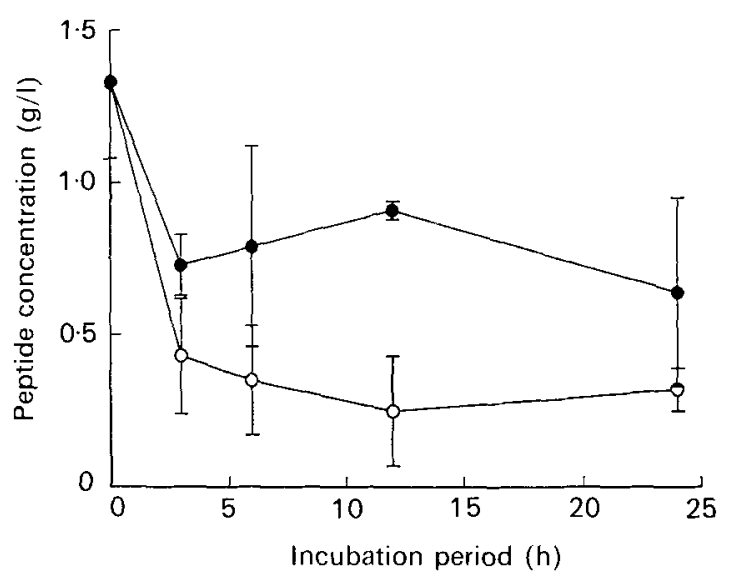

Fig. 3. Peptide disappearance following the addition of Trypticase $(O)$ and acetylated Trypticase (O) to rumen fluid in vitro. Results are means and standard deviations represented by vertical bars for rumen fluid taken from four sheep.

Table 1. Expt 3. Influence of acetylation on the breakdown of individual peptides by rumen micro-organisms*

(Values are means of duplicate incubations with strained rumen fluid pooled from four sheep)

\begin{tabular}{|c|c|c|c|c|c|c|c|}
\hline \multirow[b]{3}{*}{ Peptide } & \multirow[b]{3}{*}{ Molecular wt } & \multicolumn{6}{|c|}{ Peptide remaining in rumen fluid $(\mathrm{mg} / \mathrm{ml}$ ) } \\
\hline & & \multicolumn{3}{|c|}{ Non-acetylated } & \multicolumn{3}{|c|}{ Acetylated } \\
\hline & & $\mathrm{l} \mathrm{h}$ & $3 \mathrm{~h}$ & $6 \mathrm{~h}$ & $1 \mathrm{~h}$ & $3 \mathrm{~h}$ & $6 \mathrm{~h}$ \\
\hline Bradykinin & 1240 & 0 & 0 & 0 & 0.56 & 0.22 & 0 \\
\hline Angiotensin III & 931 & $1 \cdot 12$ & 0.17 & 0 & $1 \cdot 72$ & 0.74 & $0 \cdot 31$ \\
\hline Arg-Lys-Asp-Val-Tyr & 680 & 1.09 & $0 \cdot 40$ & 0 & 0.77 & $0 \cdot 16$ & 0 \\
\hline Val-Gly-Ser-Glu & 401 & $1 \cdot 24$ & 0.42 & 0.02 & 1.86 & 2.00 & $2 \cdot 00$ \\
\hline Gly-Gly-Phe-Leu & 393 & 0.73 & 0 & 0 & 1.67 & 0.95 & $0 \cdot 28$ \\
\hline Phe-Gly-Gly & 279 & 1.35 & $0 \cdot 43$ & 0.06 & $1.44 \div$ & 1.39 & 1.39 \\
\hline Leu-Gly-Gly & 245 & 1.43 & 0.44 & 0 & 1.97 & $2 \cdot 00$ & $2 \cdot 00$ \\
\hline Ala-Ala-Ala & 231 & 0.83 & 0.02 & 0.03 & $2 \cdot 00$ & $2 \cdot 00$ & 1.97 \\
\hline Ala-Ala & 160 & $1 \cdot 26$ & $0 \cdot 10$ & $0 \cdot 11$ & $2 \cdot 03$ & $2 \cdot 00$ & 2.00 \\
\hline
\end{tabular}

* For details of procedures, see pp. 366-367.

$\uparrow$ Only $71 \%$ acetylation was achieved with Phe-Gly-Gly; initial concentration $1.42 \mathrm{mg} / \mathrm{ml}$.

Table 2. Influence of acetylated peptides on the breakdown of non-acetylated peptides in rumen fluid in vitro

(Mean values with their standard errors for samples of rumen fluid from four sheep)

\begin{tabular}{|c|c|c|c|c|}
\hline \multirow[b]{3}{*}{ Substrate } & \multicolumn{4}{|c|}{$\begin{array}{c}\text { Rate of breakdown } \\
\text { (nmol/min per mg protein) }\end{array}$} \\
\hline & \multicolumn{2}{|c|}{ No addition } & \multicolumn{2}{|c|}{$+N$-Acetyl Ala } \\
\hline & Mean & $\mathrm{SE}$ & Mean & $\mathrm{SE}$ \\
\hline $\mathrm{Ala}_{3}$ & 6.92 & 0.55 & 6.08 & 0.55 \\
\hline $\mathrm{Al} \mathbf{a}_{4}$ & 8.01 & 0.36 & 6.91 & $0 \cdot 40$ \\
\hline
\end{tabular}

$\mathrm{Ala}_{3}$, Ala-Ala-Ala; Ala ${ }_{4}$, Ala-Ala-Ala-Ala. 
concentration of acetylated peptides present in rumen fluid. Both these applications introduced uncertainties in interpreting the results. In Expt 2, in which Trypticase and lactalbumin hydrolysate were acetylated, Sephadex G-10 was used to separate acetylated peptides from sodium acetate and acetic anhydride. About $15 \%$ of the peptide material was lost in the sodium acetate and acetic anhydride fractions from both Trypticase and lactalbumin hydrolysate, which had fairly similar elution profiles. However, these fractions contained small peptides which it can be assumed would be effectively protected by acetylation. In subsequent experiments acetic anhydride was removed by evaporation, leaving acetylated peptides mixed with sodium acetate, with no apparent effect on the results (R. J. Wallace, unpublished results). A similar procedure was used with acetylated pure peptides in the present study.

The second gel filtration technique was developed to overcome the analytical problem of estimating total concentrations of acetyl peptides in rumen fluid. Most standard techniques for the estimation of peptide concentrations, such as ninhydrin or fluorescamine, require the presence of a free N-terminus, which is obviously not available in acetylated peptides. Samples were fractionated on Sephadex G-25, and fractions corresponding to molecular weights of $300 \mathrm{Da}$ and above were analysed for u.v. absorbance and compared with controls in which no peptides had been added. The difference in $A_{206}$ was taken to be due to peptides. The total peptide content of the sample was determined by summation. The time-profile of peptides remaining in rumen fluid as estimated by this technique (Fig. 3) was clearly the inverse of the profile of ammonia concentration (Fig. 2(c)). Thus, although the method was less than totally satisfactory, it showed clearly that it was peptides rather than amino acids or other low-molecular-weight materials which remained unhydrolysed in rumen fluid.

Practical application of these findings may include the conversion of peptide-containing hydrolysates and byproducts to materials equivalent to undegraded dietary protein. Alternatively, it may be possible to protect specific amino acids in the form of small peptides from degradation in the rumen. The acetylation method used here to block the free amino groups was one used routinely by protein chemists (Means \& Feeney, 1964). This simple procedure was used here without modification, and worked well for most peptides. No further development work was done to determine more effective or more economical methods of treatment. It may be possible to decrease the concentrations of sodium acetate and acetic anhydride, for example. Alternatively, many other chemicals are available for blocking the $\mathrm{N}$-terminus of proteins and peptides. Some may yield products with better nutritional properties than acetyl peptides.

If protected peptides are to be of nutritional value, several criteria must be fulfilled. The first is that the nutrition of the host animal must be limited by the amino acids being protected. This is frequently difficult to predict (Asplund, 1986; MacRae \& Lobley, 1986). Next, the acetylated peptide should be absorbed and hydrolysed. Information on the uptake of acetylated peptides from the ruminant gut appears to be lacking. However, carboxypeptidases are well known to occur in pancreatic secretions, and these should enable acetyl peptides to be hydrolysed from the C-terminus, releasing amino acids for absorption. Alternatively, if the intact acetyl peptide is absorbed, some ruminant tissues have enzymes that cleave $N$-acetyl amino acids from peptides (Witheiler \& Wilson, 1972; Gade \& Brown 1978). Even the N-terminal amino acid will probably become available for protein synthesis as a result of acyl amino acid hydrolase (EC 3.5.1.14; Webb, 1984) activities.

Many nutritional experiments with acetylated peptides remain to be done, therefore, in order to confirm their potential value in ruminant nutrition. Furthermore, experiments will have to be conducted to ensure that the rumen microbial population does not respond to the presence of $\mathrm{N}$-acetyl peptides by enriching for species with carboxypeptidase or $\mathrm{N}$ - 
acetylamino acid acylase activities. Whether such an adaptation would occur is impossible to predict.

I am grateful to Mrs N. McKain for technical assistance.

\section{REFERENCES}

Annison, E. F. (1956). Nitrogen metabolism in the rumen. Biochemical Journal 64, 705-714.

Asplund, J. M. (1986). Somatic nutrient requirements of ruminants. Annual Review of Nutrition 6, 95-112,

Broderick, G. A. \& Balthrop, J. E. (1979). Chemical inhibition of amino acid deamination by ruminal microbes in vitro. Journal of Animal Science 49, 1101-1111.

Broderick, G. A. \& Wallace, R. J. (1988). Effects of dietary nitrogen source on concentrations of ammonia, free amino acids and fuorescamine-reactive peptides in the sheep rumen. Journal of Animal Science 66, 2233-2238.

Broderick, G. A., Wallace, R. J. \& Ørskov, E. R. (1991). Control of rate and extent of protein degradation. In Physiological Aspects of Digestion and Metabolism in Ruminants, pp. 54]-592 [T. Tsuda, Y. Sasaki and R. Kawashima, editors]. London: Academic Press.

Chalupa, W. (1976). Degradation of amino acids by the mixed rumen microbial population. Journal of Animal Science 43, 828-834.

Ferguson, K. A. (1975). The protection of dietary protein and amino acids against microbial fermentation in the rumen. In Digestion and Metabolism in the Ruminant, pp. 448-464 [I. W. McDonald and A. C. 1. Warner, editors]. Armidale: University of New England Publishing Unit.

Gade, W. \& Brown, J. L. (1978). Purification and partial characterization of $N$-acyl peptide hydrolase from bovine liver. Journal of Biological Chemistry 253, 5012-5018.

Herbert, D., Phipps, P. J. \& Strange, R. E. (1971). Chemical analysis of microbial cells. In Methods in Microbiology, vol. 5B, pp. 209-344 [J. R. Norris and D. W. Ribbons, editors]. London: Academic Press.

Kaufmann, W. \& Lupping, W. (1982). Protected proteins and protected amino acids for ruminants. In Protein Contribution of Feedstuffs for Ruminants, pp. 36-75 [E. L. Miller, I. H. Pike and A. J. H. Van Es, editors]. London: Butterworths.

Leng, R. A. \& Nolan, J. V. (1984). Nitrogen metabolism in the rumen. Journal of Animal Science 67, $1072-1089$.

MacRae, J. C. \& Lobley, G. E. (1986). Interactions between energy and protein. In Control of Digestion and Metabolism in Ruminants, pp. 367-385 [L. P. Milligan, W. L. Grovum and A. Dobson, editors]. Englewood Cliffs, New Jersey: Prentice-Hall.

Means, G. E. \& Feeney, R. E. (1964). Chemical Modification of Proteins. San Francisco: Holden-Day.

Nolan, J. (1975). Quantitative models of nitrogen metabolism in sheep. In Digestion and Metabolism in the Ruminant, pp. 416-43I [I. W. McDonald and A. C. I. Warner, editors]. Armidale, A ustralia: University of New England Publishing Unit.

Storm, E. \& Ørskov, E. R. (1984). The nutritive value of rumen micro-organisms in ruminants. 4. The limiting amino acids of microbial protein in growing sheep determined by a new approach. British Journal of Nutrition 52, 613-620

Tamminga, S. (1979). Protein degradation in the forestomachs of ruminants. Journal of Animal Science 49, 1615-1630.

Wallace, R. J. (1991). Influence of acetylation on peptide breakdown by microorganisms from the sheep rumen. Animal Production 52, 572-573 Abstr.

Wallace, R. J. (1992). Gel filtration studies of peptide metabolism by rumen microorganisms. Joumal of the Science of Food and Agriculture 58, 177-184.

Wallace, R. J. \& McKain, N. (1989). Analysis of peptide metabolism by ruminal microorganisms. Applied and Environmental Microbiology 55, 2372-2376.

Wallace, R. J., Newbold, C. J. \& McKain, N. (1990). Patterns of peptide metabolism by rumen microorganisms. In The Rumen Ecosystem. The Microbial Metabolism and its Regulation, pp. 43-50 [S. Hoshino, R. Onodera, H. Minato and H. Itabashi, editors]. Tokyo, Japan Scientific Societies Press/Springer-Verlag.

Webb. E. C. (1984). Enzyme Nomenclature. London: Academic Press.

Whitehead, R., Cooke, G. H. \& Chapman, B. T. (1967). Problems associated with the continuous monitoring of ammoniacal nitrogen in river water. Automation in Analytical Chemistry 2, 377-380.

Witheiler, J. \& Wilson, D. B. (1972). The purification and characterization of a novel peptidase from sheep red cells. Journal of Biological Chemistry 247, 952-957. 